\title{
ANALISIS SEDIMEN SEKITAR KERAMBA JARING APUNG DI PERAIRAN DANAU MANINJAU TERHADAP KANDUNGAN LOGAM BERAT Fe, $\mathrm{Cu}, \mathrm{Pb}$ dan $\mathrm{Cd}$
}

\author{
Yulizar Yusuf, Zamzibar Zuki, Umiati Lukman, Fitra Rahmi \\ E-mail: yulizaryusufch@yahoo.com
}

\begin{abstract}
ABSTRAK
Penelitian tentang penentuan kandungan logam berat $\mathrm{Fe}, \mathrm{Cu}, \mathrm{Pb}$, dan $\mathrm{Cd}$ dalam sedimen di sekitar keramba jaring apung di perairan danau Maninjau telah dilakukan. Sampel sedimen diambil pada 7 titik di lokasi dimana terdapat keramba jaring apung. Selanjutnya sampel didestruksi dengan $\mathrm{HNO}_{3}$ dan $\mathrm{H}_{2} \mathrm{O}_{2}$, kemudian kandungan logam diukur dengan menggunakan Spektrofotometer Serapan Atom (SSA). Dari hasil analisis sampel sedimen danau Maninjau diperoleh kandungan logam $\mathrm{Fe}$ berkisar antara 772,77 - 946,78 mg/kg, logam Cu berkisar antara 447,92 - 531,44 mg/kg, logam Pb berkisar antara 356,81 - 483,47 mg/kg dan logam Cd berkisar antara 249,68 - 318,95 mg/kg. Hasil yang didapat menunjukkan bahwa keempat logam telah melampaui ambang batas yang telah ditetapkan oleh Roseau National d Observation.
\end{abstract}

Keywords: Logam berat, sedimen, dekstruksi

\section{PENDAHULUAN}

Tingkat pencemaran air di danau Maninjau saat ini semakin mengkhawatirkan. Air danau yang dulunya bening dan dalam, kini dangkal, keruh dan berbau. Menurut hasil dugaan sementara, danau ini tak mempunyai sirkulasi atau perputaran air lagi sejak 20 tahun lampau.

Menurut penelitian Masyarakat Peduli Air Maninjau, keruhnya air danau itu diakibatkan oleh kotoran-kotoran yang ada di permukaan danau, yang tak bisa hanyut ke luar danau melalui Muara Batang Antokan. Pasalnya, di pintu air tersebut telah berdiri intake atau saluran masuk air untuk pemutar empat turbin Pembangkit Listrik Tenaga Air Maninjau.

Dilihat dari aktivitas danau Maninjau, banyak faktor yang dapat menyebabkan kerusakan pada ekosistem air ini. Salah satunya yaitu budidaya ikan keramba. Pada konsentrasi tertentu residu pakan ikan yang menumpuk akan menjadi racun bagi ikan-ikan keramba tersebut. Akibat pemberian pakan ikan yang berlebihan setiap hari mengakibatkan terjadinya pengendapan pada dasar danau. Hal tersebut mengakibatkan berubahnya kandungan beberapa logam yang sumbernya berasal dari sedimen pakan ikan ataupun dari limbah vulkanik lainnya. Perubahan ini dapat melebihi konsentrasi logam yang diperbolehkan pada badan perairan. Sedimen penting artinya sebagai suatu ekosistem, tempat hidup dan tempat mencari makan organisme yang hidup disekitarnya. Kandungan alami logam berat dalam sedimen yang tidak terkontaminasi adalah sebesar $0,01 \mathrm{ppm}$. Sedangkan sedimen yang telah terkontaminasi dapat meningkatkan menjadi sepuluh sampai seratus kali ${ }^{[1]}$.

Oleh karena itu, maka perlu dilakukan suatu penelitian tentang kandungan logam berat $\mathrm{Fe}$, $\mathrm{Cu}, \mathrm{Pb}$ dan $\mathrm{Cd}$ dalam sedimen di sekitar keramba jaring apung danau Maninjau.

\section{METODOLOGI PENELITIAN}

\section{Waktu dan Tempat Penelitian}

Lokasi pengambilan sampel terletak di perairan danau Maninjau, Sumatera Barat. Analisis sampel dilakukan di Laboratorium Kimia Analisa Terapan Fakultas Matematika dan Ilmu Pengetahuan Alam (FMIPA) 
Universitas Andalas dan dilaksanakan pada bulan Juli sampai September 2010.

\section{Persiapan Sampel}

Pengambilan sampel sedimen dilakukan pada tanggal 6 Juli 2010 di beberapa lokasi di sekitar keramba jaring apung pada perairan danau Maninjau, Sumatera Barat. Sampel diambil dengan menggunakan alat Sedimen Grap, kemudian dimasukkan ke dalam kantong plastik untuk dibawa ke laboratorium. Sampel sedimen dihaluskan dengan lumpang dan alu.

Sampel sedimen yang telah dihaluskan dengan lumpang dan alu, kemudian dikeringkan dalam oven pada suhu $105{ }^{\circ} \mathrm{C}$ selama 3 jam. Sampel yang telah kering ditimbang dengan teliti $\pm 0,5 \mathrm{~g}$ dan dilakukan destruksi dengan memasukkan cuplikan ke dalam labu kjehdahl kemudian ditambahkan $5 \mathrm{~mL}$ asam nitrat pekat. Labu dipanaskan sambil dimasukkan $1 \mathrm{~mL} \mathrm{H}_{2} \mathrm{O}_{2} 20 \%$ setetes demi setetes sampai larutan berwarna jernih, kemudian didinginkan dan cuplikan disaring dengan kertas saring kemudian diencerkan dalam labu $25 \mathrm{~mL}$. Cuplikan siap untuk dilakukan analisis unsur.

\section{Pembuatan Larutan Standar dan Penentuan Kadar Fe dalam Sampel}

Ditimbang logam Fe 0,9997 g dan dilarutkan dalam gelas piala dengan $\mathrm{HNO}_{3} 65 \%$, kemudian dimasukan ke dalam labu ukur $1000 \mathrm{~mL}$ dan diencerkan dengan aquades sampai tanda batas, sehingga diperoleh larutan induk logam Fe 999,7 mg/L. Dipipet $10 \mathrm{~mL}$ larutan induk Fe 999,7 ppm ke dalam labu ukur $100 \mathrm{~mL}$, diencerkan tepat sampai tanda batas dengan aquades, sehingga didapatkan larutan Fe 99,97 mg/L. Dibuat pengenceran larutan standar logam $\mathrm{Fe}$ dengan variasi konsentrasi $0 ; 2,5 ; 5 ; 10 ; 15$; dan $20 \mathrm{ppm}$ dengan cara memipet masingmasing $0 ; 1,25 ; 2,5 ; 5 ; 7,5$; dan $10 \mathrm{~mL}$ larutan standar $\mathrm{Fe} 99,97 \mathrm{mg} / \mathrm{L}$ dalam labu ukur $50 \mathrm{~mL}$, dan ditepatkan volumenya hingga tanda batas dengan aquades. Diukur serapan $\mathrm{Fe}(\lambda 283 \mathrm{~nm})$ dengan menggunakan lampu katoda Fe. Dibuat kurva kalibrasi standarnya (konsentrasi Vs absorban) dan diukur absorban sesuai dengan titik lokasi pengambilan sampel. Dihitung konsentrasi logam $\mathrm{Fe}$ berdasarkan kurva kalibrasi standar.

\section{Pembuatan Larutan Standar dan Penentuan Kadar Cu dalam Sampel}

Ditimbang logam $\mathrm{Cu} 1 \mathrm{~g}$ dan dilarutkan dalam gelas piala dengan $\mathrm{HNO}_{3} 65 \%$, kemudian dimasukan ke dalam labu ukur $1000 \mathrm{~mL}$ dan diencerkan dengan aquades sampai tanda batas, sehingga diperoleh larutan induk logam Cu 1000 mg/L. Dipipet $10 \mathrm{~mL}$ larutan induk $\mathrm{Cu} 1000$ ppm ke dalam labu ukur $100 \mathrm{~mL}$, diencerkan tepat sampai tanda batas dengan aquades, sehingga didapatkan larutan baku $\mathrm{Cu} 100 \mathrm{mg} / \mathrm{L}$. Dibuat pengenceran larutan standar logam $\mathrm{Cu}$ dengan variasi konsentrasi $0 ; 2 ; 6 ; 8 ; 10$; dan $15 \mathrm{mg} / \mathrm{L}$ dengan cara memipet masingmasing $0 ; 1 ; 3 ; 4 ; 5$; dan $7,5 \mathrm{~mL}$ larutan standar $100 \mathrm{mg} / \mathrm{L}$ masing-masing logam dalam labu ukur $50 \mathrm{~mL}$, ditepatkan volumenya hingga tanda batas dengan aquades. Diukur serapan sebanyak 2 kali ulangan masing-masing sampel untuk logam $\mathrm{Cu}(\lambda 324,7 \mathrm{~nm})$ dengan menggunakan lampu katoda $\mathrm{Cu}$. Dibuat kurva kalibrasi standarnya (konsentrasi Vs absorban) dan diukur absorban sesuai dengan titik lokasi pengambilan sampel. Dihitung konsentrasi logam $\mathrm{Cu}$ berdasarkan kurva kalibrasi standar.

\section{Pembuatan Larutan Standar dan Penentuan Kadar Pb dalam Sampel}

Ditimbang logam $\mathrm{Pb} 1,0012 \mathrm{~g}$ dan dilarutkan dalam gelas piala dengan $\mathrm{HNO}_{3} 65 \%$, kemudian dimasukan ke dalam labu ukur $1000 \mathrm{~mL}$ dan diencerkan dengan aquades sampai tanda batas, sehingga diperoleh larutan induk logam $\mathrm{Pb} 1001,2 \mathrm{mg} / \mathrm{L}$. Dipipet $10 \mathrm{~mL}$ larutan induk $\mathrm{Pb}$ 1001,2 ppm ke dalam labu ukur $100 \mathrm{~mL}$, diencerkan tepat sampai tanda batas dengan aquades, sehingga didapatkan larutan baku $\mathrm{Pb} 100,12 \mathrm{mg} / \mathrm{L}$. Dibuat pengenceran larutan standar logam $\mathrm{Pb}$ dengan variasi konsentrasi $0,2,4,6,8$ dan 10 ppm dengan cara memipet masing-masing 0 ; 0,$99 ; 1,99 ; 2,99 ; 3,99$; dan $4,99 \mathrm{~mL}$ larutan standar $\mathrm{Pb} 100,12 \mathrm{mg} / \mathrm{L}$ dalam labu ukur 50 $\mathrm{mL}$, dan ditepatkan volumenya hingga tanda batas dengan aquades. Diukur serapan sebanyak 2 kali ulangan masing-masing 
sampel untuk logam $\mathrm{Pb}(\lambda 217 \mathrm{~nm})$ dengan menggunakan lampu katoda yang sesuai dengan logam yang akan dianalisis. Dibuat kurva kalibrasi standarnya (konsentrasi Vs absorban). Diukur absorban sesuai dengan titik lokasi pengambilan. Konsentrasi masing-masing logam dihitung berdasarkan kurva kalibrasi standar.

\section{Pembuatan Larutan Standar dan Penentuan Kadar Cd dalam Sampel}

Ditimbang logam $\mathrm{Cd} 1 \mathrm{~g}$ dan dilarutkan dalam gelas piala dengan $\mathrm{HNO}_{3} 65 \%$, kemudian dimasukan ke dalam labu ukur $1000 \mathrm{~mL}$ dan diencerkan dengan aquades sampai tanda batas, sehingga diperoleh larutan induk logam Cd $1000 \mathrm{mg} / \mathrm{L}$. Dipipet $10 \mathrm{~mL}$ larutan induk Cd 1000 ppm ke dalam labu ukur $100 \mathrm{~mL}$, diencerkan tepat sampai tanda batas dengan aquades, sehingga didapatkan larutan baku Cd $100 \mathrm{mg} / \mathrm{L}$. Buat pengenceran larutan standar logam $\mathrm{Cd}$ dengan variasi konsentrasi $0,2,4,6,8$, dan $10 \mathrm{ppm}$ dengan cara memipet masing-masing $0,1,2,3,4$, dan $5 \mathrm{~mL}$ larutan standar 100 $\mathrm{mg} / \mathrm{L}$ masing-masing logam dalam labu ukur $50 \mathrm{~mL}$, ditepatkan volumenya hingga tanda batas dengan aquades. Diukur serapan sebanyak 2 kali ulangan masing-masing sampel untuk logam $\mathrm{Cd}(\lambda 228,8 \mathrm{~nm})$ dengan menggunakan lampu katoda yang sesuai dengan logam yang akan dianalisis. Dibuat kurva kalibrasi standarnya (konsentrasi Vs absorban).Diukur absorban sesuai dengan titik lokasi pengambilan. Dihitung konsentrasi masing-masing logam berdasarkan kurva kalibrasi standar.

\section{Pengolahan Data}

Data diolah dengan menggunakan cara statistik yang dimulai dengan perhitungan Standar Deviasi dan dilanjutkan menentukan rentang ${ }^{[2]}$. Jika hasilnya signifikan maka dilanjutkan dengan uji Varians atau uji Duncant ${ }^{[3]}$.

\section{HASIL DAN PEMBAHASAN}

\section{Persamaan Regresi Larutan Standar}

Keempat persamaan regresi deretan larutan standar diatas diperoleh dari data penentuan absorban larutan standar. Dari data tersebut dengan menggunakan perhitungan statistik. Maka dapat diperoleh persamaan garis regresi dan koefisien korelasi.

Tabel 1. Persamaan Regresi Larutan Standar.

\begin{tabular}{c|cc}
\hline Logam & Persamaan Regresi & $\mathbf{R}^{2}$ \\
\hline $\mathrm{Fe}$ & $\mathrm{y}=0,031 \mathrm{x}+0,001$ & 0,999 \\
$\mathrm{Cu}$ & $\mathrm{y}=0,036 \mathrm{x}+0,007$ & 0,998 \\
$\mathrm{~Pb}$ & $\mathrm{y}=0,028 \mathrm{x}+0,001$ & 0,999 \\
$\mathrm{Cd}$ & $\mathrm{y}=0,042 \mathrm{x}+0,010$ & 0,997 \\
\hline
\end{tabular}

\section{Hasil Analisis Konsentrasi Logam pada Sedimen}

Di bawah ini merupakan konsentrasi logam $\mathrm{Fe}, \mathrm{Cu}, \mathrm{Pb}$ dan $\mathrm{Cd}$ dalam sedimen disekitar keramba jaring apung danau Maninjau. Konsentrasi masing-masing logam dihitung dengan memasukan nilai absorban dari setiap pengukuran ke dalam persamaan garis regresi.
Konsentrasi masing-masing logam dinyatakan dalam satuan $\mathrm{mg} / \mathrm{kg}$ berat kering.

Jika dilihat pada Tabel 2 terlihat bahwa kandungan logam $\mathrm{Fe}, \mathrm{Cu}, \mathrm{Pb}$ dan $\mathrm{Cd}$ pada 7 lokasi sampel yang berada di sekitar keramba jaring apung ada perbedaan yang sangat nyata (significant). Hal ini disebabkan karena kondisi biogeokimia di masing masing lokasi berbeda. 
Tabel 2. Konsentrasi logam $\mathrm{Fe}, \mathrm{Cu}, \mathrm{Pb}$ dan $\mathrm{Cd}$ dalam sedimen disekitar keramba jaring apung danau Maninjau (mg/kg).

\begin{tabular}{|c|c|c|cc|}
\hline Lokasi & Fe & $\mathbf{C u}$ & $\mathbf{P b}$ & $\mathbf{C d}$ \\
\hline 1 & 780,57 & 508,75 & 356,81 & 249,68 \\
\hline 2 & 899,15 & 531,44 & 371,09 & 300,28 \\
\hline 3 & 946,78 & 447,92 & 447,31 & 267,86 \\
\hline 4 & 772,77 & 486,29 & 417,13 & 266,82 \\
\hline 5 & 825,79 & 504,93 & 370,89 & 311,29 \\
\hline 6 & 905,85 & 498,40 & 471,27 & 318,95 \\
\hline 7 & 843,52 & 507,85 & 483,47 & 315,15 \\
\hline
\end{tabular}

Berdasarkan kisaran kadar alamiah menunjukkan bahwa batasan kadar logam untuk semua logam dari semua lokasi telah melebihi batas ambang batas yang ditetapkan ${ }^{[6]}$. Hasil yang sama juga diperoleh para penelitian lain ${ }^{[4]}$.

Kadar Logam $\mathrm{Fe}, \mathrm{Cu}, \mathrm{Pb}$ dan $\mathrm{Cd}$ pada Sedimen Danau Maninjau dengan 7 lokasi disekitar keramba jaring apung memiliki kadar yang berbeda. Diperoleh kadar logam Fe berkisar antara $772,77-946,78 \mathrm{mg} / \mathrm{kg}$. Kadar logam $\mathrm{Cu}$ berkisar antara 447,92 $531,44 \mathrm{mg} / \mathrm{kg}$. Kadar logam $\mathrm{Pb}$ berkisar antara $356,81-483,47 \mathrm{mg} / \mathrm{kg}$. Kadar logam Cd berkisar antara 249,68-318,95 mg/kg.

Dari keempat logam tersebut didapatkan bahwa logam $\mathrm{Fe}$ yang memiliki konsentrasi paling tinggi. Hasil penelitian yang dilakukan oleh peneliti peneliti lain juga menunjukkan kecenderungan yang sama, dimana kandungan logam $\mathrm{Fe}$ lebih tinggi bila dibandingkan dengan logam logam yang lain $^{[7,8]}$. Hal ini dapat disebabkan karena logam Fe memiliki kelimpahan yang tinggi di alam $^{[9,12]}$ dan danau Maninjau merupakan danau vulkanik. Selain itu, Fe juga berasal dari pakan ikan dimana petani ikan pada umumnya memberikan pakan ikan (pelet) tidak sesuai aturan, sehingga pakan tersebut tidak termakan oleh ikan yang mengakibatkan pakan ikan tersebut mengendap di dasar danau.
Kadar logam yang terendah adalah logam $\mathrm{Cd}$. Hal ini disebabkan karena sumber $\mathrm{Cd}$ itu sendiri hanya sedikit yang masuk kedalam danau dan biasanya $\mathrm{Cd}$ bersumber dari industri plastik dan elektroplating ${ }^{[5]}$. Peneliti peneliti lain juga memperoleh hasil yang sama dimana kadar $\mathrm{Cd}$ terendah dari logamlogam lain.

\section{Konsentrasi Logam Berat $\mathrm{Fe}, \mathrm{Cu}, \mathrm{Pb}$ dan Cd dalam Sedimen}

Konsentasi logam berat yang terdapat pada sedimen jika dinyatakan dalam bentuk diagram batang maka dapat dilihat pada gambar dibawah ini. Perhitungan konsentrasi dilanjutkan secara statistik untuk menentukan standar deviasi dan uji beda nyata (significant).

Perbedaan hasil yang sangat nyata dapat disebabkan oleh jumlah keramba, lamanya sedimentasi di dasar danau dan adanya mata air dibawah sedimen sehingga membawa serta ion-ion logam ke permukaan. Dengan adanya sedimentasi mengakibatkan ion-ion logam yang terdapat di dasar danau terserap lebih banyak. Konsentrasi $\mathrm{Fe}$ yang dinyatakan berbeda nyata (significant) secara statistik terdapat antara lokasi 1 dengan 2 , lokasi 2 dengan 3, lokasi 3 dengan 4, lokasi 4 dengan 5, lokasi 5 dengan 6 , dan lokasi 6 dengan 7. Sedangkan konsentrasi Fe yang dinyatakan tidak berbeda nyata (nonsignificant) secara statistik terdapat antara 
lokasi 1 dengan 4, lokasi 5 dengan 7, dan lokasi 2 dengan 6 .

Pada Gambar 1 menunjukkan hasil pengukuran kadar logam $\mathrm{Fe}$ pada sedimen danau Maninjau dengan 7 lokasi disekitar keramba jaring apung yang berbeda.
Diperoleh kadar logam Fe berkisar antara $772,78-946,78 \mathrm{mg} / \mathrm{kg}$. Dari diagram batang terlihat bahwa pada lokasi 3 dan 4 ada perbedaan nyata sesuai seperti pada tabel anova. Sedangkan pada lokasi 1 dan 4 tidak ada perbedaan yang nyata.

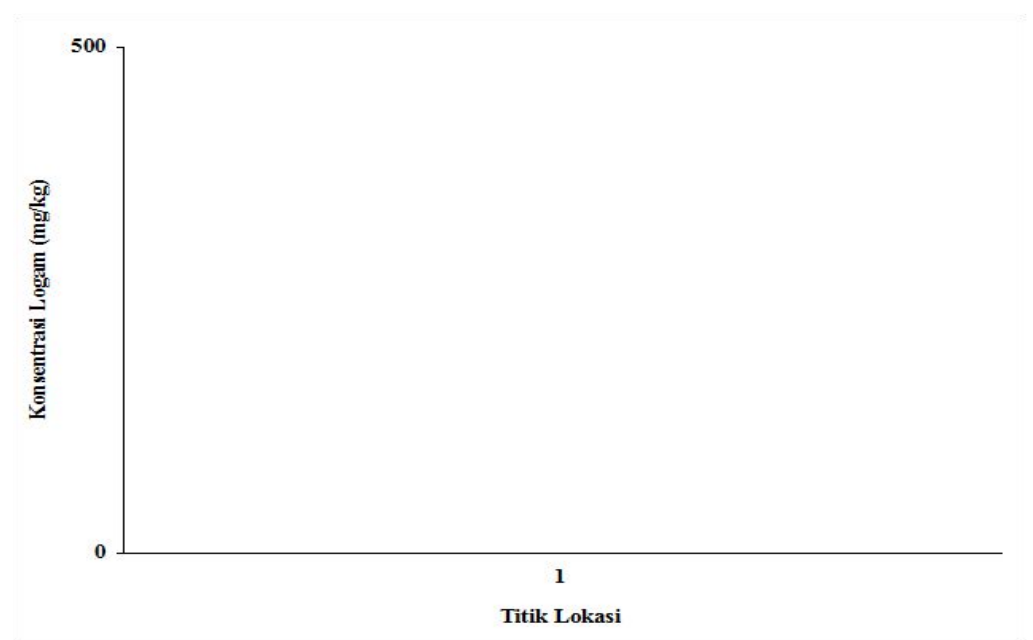

Gambar 1. Hasil analisis konsentrasi logam Fe pada sedimendi sekitar keramba danau Maninjau.

Konsentrasi $\mathrm{Cu}$ yang dinyatakan berbeda nyata (significant) secara statistik terdapat antara lokasi 1 dengan 2, lokasi 2 dengan 3, dan lokasi 3 dengan 4 . Sedangkan konsentrasi $\mathrm{Cu}$ yang dinyatakan tidak berbeda nyata (non-significant) secara statistik terdapat antara lokasi 3 dengan 6 , lokasi 1 dengan 4 , lokasi 1 dengan 5, lokasi 1 dengan 6, lokasi 1 dengan 7, lokasi 4 dengan 5, lokasi 4 dengan 6 , lokasi 4 dengan 7, lokasi 5 dengan 6 dan lokasi 6 dengan7.
Pada Gambar 2 menunjukkan hasil pengukuran kadar logam cu pada sedimen danau Maninjau dengan 7 lokasi disekitar keramba jaring apung yang berbeda. Diperoleh kadar logam $\mathrm{Cu}$ berkisar antara $447,92-531,44 \mathrm{mg} / \mathrm{kg}$. Dari diagram batang terlihat bahwa pada lokasi 2 dan 3 ada perbedaan nyata sesuai seperti pada Tabel anova. Sedangkan pada lokasi 1 dan 4 tidak ada perbedaan yang nyata.

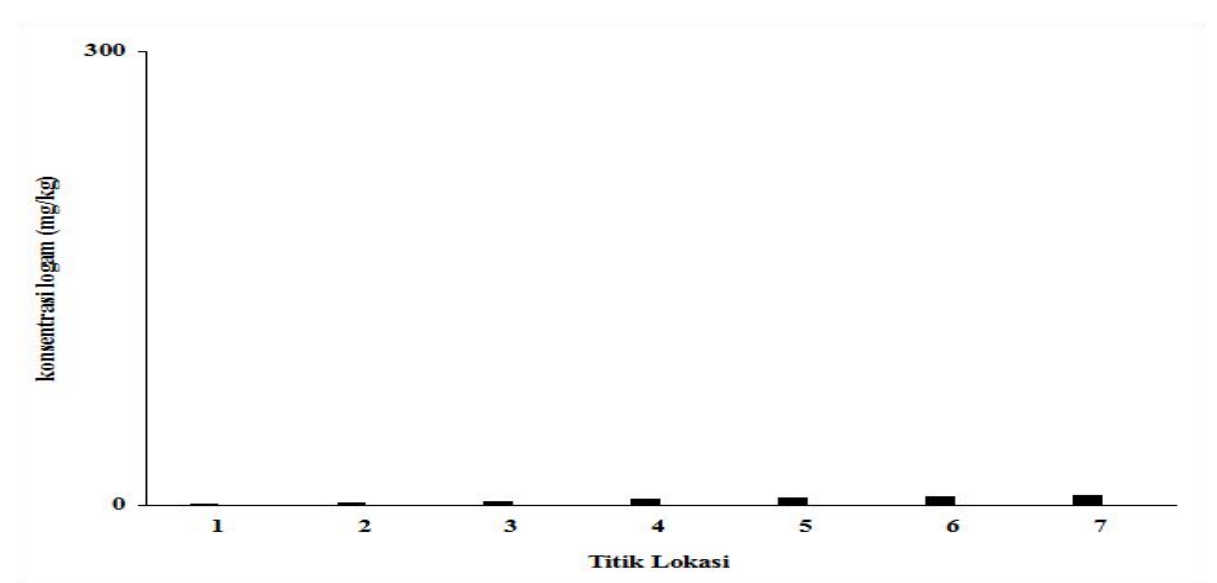

Gambar 2. Hasil analisis konsentrasi logam Cu pada sedimen di keramba Danau Maninjau. 
Konsentrasi $\mathrm{Pb}$ yang dinyatakan berbeda nyata (significant) secara statistik terdapat antara lokasi 2 dengan 3, lokasi 3 dengan 4, lokasi 4 dengan 5 , dan lokasi 5 dengan 6 . Sedangkan konsentrasi $\mathrm{Pb}$ yang dinyatakan tidak berbeda nyata (non-significant) secara statistik terdapat antara lokasi 1 dengan 2 , lokasi 1 dengan 5, lokasi 2 dengan 5, dan lokasi 6 dengan 7 .

Pada Gambar 3 menunjukkan hasil pengukuran kadar logam pb pada sedimen danau Maninjau dengan 7 lokasi disekitar keramba jaring apung yang berbeda. lokasi 3 dengan 4, lokasi 1 dengan 4, lokasi 2 dengan 5, lokasi 5 dengan 6 , lokasi 6 dengan
Diperoleh kadar logam $\mathrm{Pb}$ berkisar antara $356,81-483,47 \mathrm{mg} / \mathrm{kg}$. Dari diagram batang terlihat bahwa pada lokasi 5 dan 6 ada perbedaan nyata sesuai seperti pada Tabel anova. Sedangkan pada lokasi 1 dan 2 tidak ada perbedaan yang nyata.

Konsentrasi $\mathrm{Cd}$ yang dinyatakan berbeda nyata (significant) secara statistik terdapat antara lokasi 1 dengan 2, lokasi 2 dengan 3, dan lokasi 4 dengan 5. Sedangkan konsentrasi $\mathrm{Cd}$ yang dinyatakan tidak berbeda nyata (non-significant) secara statistik terdapat antara lokasi 1 dengan 3, 7, lokasi 5 dengan 7, lokasi 2 dengan 6 , dan lokasi 2 dengan 7 .

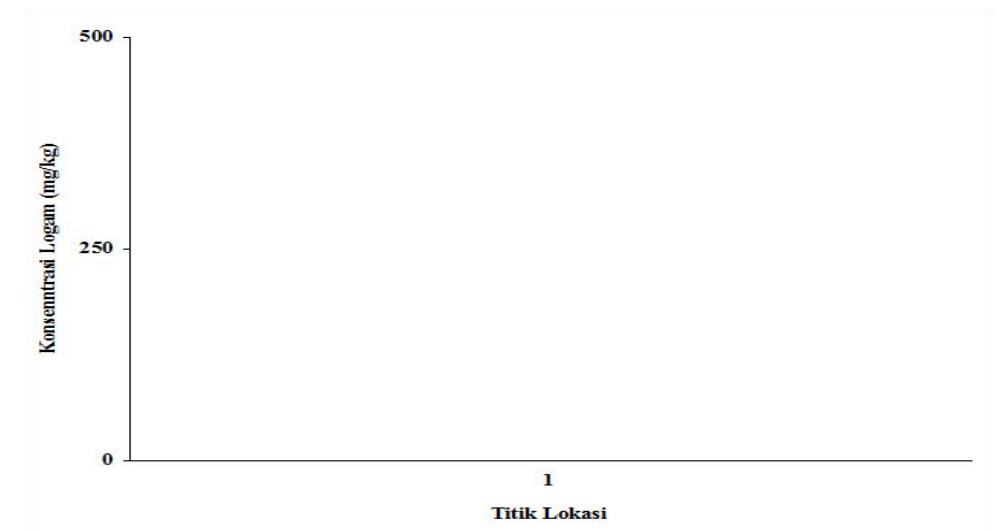

Gambar 3. Hasil analisis konsentrasi logam $\mathrm{Pb}$ pada sedimen di keramba danau Maninjau.

Pada Gambar 4 menunjukkan hasil pengukuran kadar logam $\mathrm{Cd}$ pada sedimen danau Maninjau dengan 7 lokasi disekitar keramba jaring apung yang berbeda. Diperoleh kadar logam $\mathrm{Cd}$ berkisar antara
$249,68-318,95 \mathrm{mg} / \mathrm{kg}$. Dari diagram batang terlihat bahwa pada lokasi 1 dan 2 ada perbedaan nyata sesuai seperti pada Tabel anova. Sedangkan pada lokasi 3 dan 4 tidak ada perbedaan yang nyata.

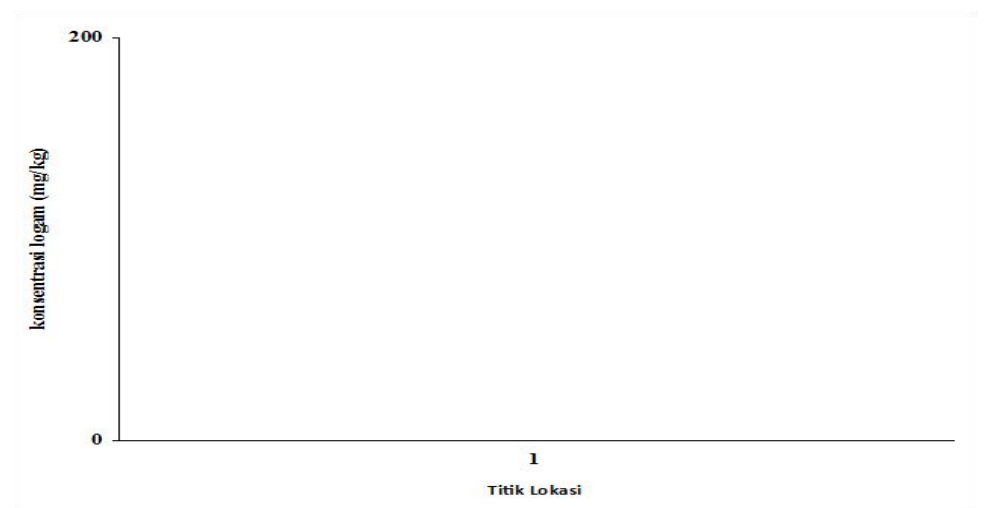

Gambar 4. Hasil analisis konsentrasi Logam Cd pada sedimendi keramba danau Maninjau. 


\section{KESIMPULAN}

Berdasarkan hasil penelitian analisis kandungan logam $\mathrm{Fe}, \mathrm{Cu}, \mathrm{Pb}$ dan $\mathrm{Cd}$ dalam sedimen di sekitar keramba jaring apung danau Maninjau, maka dapat disimpulkan bahwa kandungan logam berat $\mathrm{Fe}$ berkisar antara $772,77-946,78 \mathrm{mg} / \mathrm{kg}$, logam $\mathrm{Cu}$ berkisar antara 447,92 - 531,44 mg/kg, logam $\mathrm{Pb}$ berkisar antara 356,81 - 483,47 $\mathrm{mg} / \mathrm{kg}$ dan logam Cd berkisar antara 249,68 $318,95 \mathrm{mg} / \mathrm{kg}$. Dilihat berdasarkan hasil analisis dan dibandingkan dengan kisaran kadar alamiah dalam sedimen (RNO, 1981 dalam Razak, 1986) menunjukkan bahwa batasan kadar logam dari semua lokasi telah melebihi ambang batas yang telah ditetapkan, sehingga air danau Maninjau tidak layak digunakan sebagai tempat budidaya ikan keramba.

\section{DAFTAR PUSTAKA}

1. J. M. Everaarta, Heavy metals $(\mathrm{Cu}, \mathrm{Zn}$, $\mathrm{Pb}, \mathrm{Cd}$ ) in sediment of the save sea, eaturine and coastal areas of east java and some deep sea areas in : Netherland, Journal of Sea Research., 23(4): 403413, (1989).

2. E. Sugandi dan Sugiarto. Rancangan percobaan teori dan aplikasi anova. Andi offset Yogyakarta.1993.

3. L. Anderson and Robert. Practical statistic for analytical chemist. Newyork. 1987.

4. Mohamed, H. H. Ali, Amaal, and M. Abdel-Satar. The journal studies of some heavy metals in water, sediment, fish and fish diets in some fish farms in el-fayoum province, Egypt., 261-273, (2005).

5. H. Palar, Pencemaran dan toksikologi logam berat. Rineka Cipta. 1994.

6. H. Razak, Kisaran kadar alamiah logam berat dalam sedimen (Roseau National d observation), LION-LIPI, Jakarta, 1986.

7. M. Ozturk, G. Ozozen, and O. Minareci, Determination of heavy metals in fish, water and sediments of avsar dam lake in Turkey Iran, J.environ. Health Sci.eng., 6(2): 73-80, (2009).

8. S. M. Saeed and I. M. Shaker. Assessment of metals pollution in water and sediments and their effect on oreochromis niloticus in the northern delta lake, Egypt. 8th Internatonal Symposium on Tilapia Aquaculture., 475-489, (2008).

9. A. Osman, Water quality and heavy metal monitoring in water, sediments and tissues of the African catfish clarias gariepinus from the river nile, egypt. Journal of Evironmental Protection., 1: 389-400, (2010).

10. M. Al-Kahtani, Accumulation of heavy metal in tilapia fish (oreochromis niloticus) from al-khadoud spring, AlHassa, Saudi Arabia. American Journal of Applied Sciences., 6(12): 2024-2028.

11. S. E. Manahan, Toxicological chemistry and biochemistry. $3^{\text {th }}$ edition. Unites States of America: Lewis Publisher, 2003.

12. H. Karadede and E. Unlu, Concentrations of same heavy metals in water, sediment and fish species from the ataturk dam lake (Euprates), Turkey. Chemosphere., 41(9): 1371-1376. 